\title{
Stability of free and encapsulated Lactobacillus acidophilus ATCC 4356 in yogurt and in an artificial human gastric digestion system
}

\author{
F. Ortakci ${ }^{*}{ }^{1}$ and S. Sert $†$ \\ *Western Dairy Center, Utah State University, Logan 84322-8700 \\ †Ataturk University, Faculty of Agriculture, Department of Food Engineering, 25240 Erzurum, Turkey
}

\begin{abstract}
The objective of this study was to determine the effect of encapsulation on survival of probiotic Lactobacillus acidophilus ATCC 4356 (ATCC 4356) in yogurt and during artificial gastric digestion. Strain ATCC 4356 was added to yogurt either encapsulated in calcium alginate or in free form (unencapsulated) at levels of 8.26 and $9.47 \mathrm{log} \mathrm{cfu} / \mathrm{g}$, respectively, and the influence of alginate capsules (1.5 to $2.5 \mathrm{~mm}$ ) on the sensorial characteristics of yogurts was investigated. The ATCC 4356 strain was introduced into an artificial gastric solution consisting of $0.08 \mathrm{~N} \mathrm{HCl}(\mathrm{pH}$ 1.5) containing $0.2 \% \mathrm{NaCl}$ or into artificial bile juice consisting of $1.2 \%$ bile salts in de Man, Rogosa, and Sharpe broth to determine the stability of the probiotic bacteria. When incubated for $2 \mathrm{~h}$ in artificial gastric juice, the free ATCC 4356 did not survive (reduction of $>7 \log \mathrm{cfu} / \mathrm{g}$ ). We observed, however, greater survival of encapsulated ATCC 4356, with a reduction of only $3 \mathrm{log} \mathrm{cfu} / \mathrm{g}$. Incubation in artificial bile juice $(6 \mathrm{~h})$ did not significantly affect the viability of free or encapsulated ATCC 4356. Moreover, statistically significant reductions $(\sim 1 \log \mathrm{cfu} / \mathrm{g})$ of both free and encapsulated ATCC 4356 were observed during 4-wk refrigerated storage of yogurts. The addition of probiotic cultures in free or alginate-encapsulated form did not significantly affect appearance/color or flavor/odor of the yogurts. However, significant deficiencies were found in body/ texture of yogurts containing encapsulated ATCC 4356. We concluded that incorporation of free and encapsulated probiotic bacteria did not substantially change the overall sensory properties of yogurts, and encapsulation in alginate using the extrusion method greatly enhanced the survival of probiotic bacteria against an artificial human gastric digestive system.
\end{abstract}

Key words: probiotic, encapsulation, gastric, yogurt

Received May 10, 2012.

Accepted July 29, 2012.

${ }^{1}$ Corresponding author: fatih.ortakci@usu.edu

\section{INTRODUCTION}

The ability of probiotic bacteria to provide various health benefits (Krasaekoopt et al., 2003; Singh et al., 2011) depends on their ability to survive passage through the gastrointestinal tract (Champagne et al., 2005; Stanton et al., 2005) in sufficient numbers $\left(10^{8}\right.$; Lourens-Hattingh and Viljoen, 2001). According to Antoine (2011), probiotic delivery in food faces dual challenges of surviving refrigerated storage $\left(\sim 4^{\circ} \mathrm{C}\right)$, followed by transition to mouth temperature $\left(\sim 25^{\circ} \mathrm{C}\right)$, and then to body temperature $\left(\sim 37^{\circ} \mathrm{C}\right)$ in the gastrointestinal tract, followed by the chemical challenge as the bacteria enters the hyper-acidic (fasting $\mathrm{pH}$ of around 1 to 2) environment of the stomach, and finally by rapid neutralization to $\mathrm{pH} 7.5$ and the detergent bile salts in the duodenum.

In order for probiotics to provide a metabolic function in the gut of host, they must be delivered to the human gut (Mattila-Sandholm et al., 2002; Krasaekoopt et al., 2003; Champagne et al., 2005; Stanton et al., 2005). Losses of 6 to $8 \log \mathrm{cfu} / \mathrm{g}$ of probiotic bacteria using artificial gastric digestion have been reported (Hansen et al., 2002; Muthukumarasamy et al., 2006; Sabikhi et al., 2010; Brinques and Ayub, 2011), which implies that the recommended $10^{7} \mathrm{cfu} / \mathrm{g}$ of bacteria in a probiotic food system throughout shelf life (Ouwehand and Salminen, 1998) may not be sufficient to exert health beneficial effects. Although it is well known that the food matrix itself protects bacteria during gastric passage, Sharp et al. (2008) have shown that this may not be the case if no buffering occurs. In other words, yogurt alone is not a good protector of probiotic bacteria in artificial gastric conditions when the $\mathrm{pH}$ maintained at $\mathrm{pH}$ 2.3. Providing increased protection to probiotics during gastric passage positively influences their health-promoting effects.

Encapsulation as a technology for improving the survival of probiotics in in vitro gastric solutions and during storage has been studied in several dairy foods, including yogurt (Sultana et al., 2000; Krasaekoopt et al., 2006), Turkish kasar and white cheeses (Ozer et al., 2008, 2009), and ice cream (Homayouni et al., 2008). For example, Krasaekoopt et al. (2006) reported a loss 
of approximately $1 \log$ of encapsulated Lactobacillus acidophilus compared with a 2-log loss of free bacteria over $4 \mathrm{wk}$ of refrigerated storage of yogurts. Moreover, Kailasapathy (2006) reported losses of 4 and $2 \log$ of free and encapsulated $L b$. acidophilus DD910, respectively, over 6-wk refrigerated storage of yogurts.

Survival in gastric conditions has also been studied, and increased survival via encapsulation varies depending on capsule size and gastric juice conditions. Better survival occurs with larger capsules and higher $\mathrm{pH}$ of the gastric juice. Kim et al. (2008) observed 3-log reductions in the numbers of $L b$. acidophilus ATCC 43121 encapsulated in alginate via an extrusion method and no survival of free ATCC 43121 in artificial gastric juice (AGJ; pH 1.2 and 1.5). Mandal et al. (2006) found that encapsulated $L b$. casei NCDC-298 had better survival (2 log) than free NCDC-298 during a 3-h incubation in AGJ (pH 1.5). Likewise, Sabikhi et al. (2010) reported that encapsulated (using alginate and starch) cells of Lb. acidophilus LA1 survived the artificial gastric conditions ( $\mathrm{pH} 1.5$ for $2 \mathrm{~h}$ ) better than the free form of the same strain. They observed 2- and 4.5-log losses of encapsulated and free LA1 during $2 \mathrm{~h}$ incubation at $\mathrm{pH}$ 1.5, respectively. Ding and Shah (2009) reported better survival of alginate-encapsulated $L b$. acidophilus after incubation at $\mathrm{pH} 2$ for $2 \mathrm{~h}$. They observed that free $L b$. acidophilus cells had a $\sim 7-\log$ reduction (10.7 to 3.8) compared with alginate-encapsulated $L b$. acidophilus cells, which had only a 3.5-log reduction after $2 \mathrm{~h}$ of incubation in high acid conditions.

Although larger capsules provide better protection (Muthukumarasamy et al., 2006), they are more likely to influence the textural properties of the food. However, we have not found any reports in the literature on the effect of large calcium alginate capsules $(>1 \mathrm{~mm})$ containing probiotic bacteria on the sensorial characteristics and acceptability of a smooth-textured product such as yogurt. To fill this gap, we manufactured probiotic yogurt with Lactobacillus acidophilus ATCC 4356 encapsulated in large Ca-alginate capsules to provide gastric protection and then evaluated sensory properties and acceptability of the yogurt. Survivability was measured periodically during 4 wk of refrigerated storage of yogurt and after incubation in artificial gastric and bile juices. Following this, sensory evaluations, using trained panelists, were performed on yogurt, which was evaluated for appearance and color, body and texture, flavor, odor, and overall liking.

\section{MATERIALS AND METHODS}

\section{Materials}

Lactobacillus acidophilus ATCC 4356 probiotic strain was obtained from Microbiologics Inc. (St. Cloud, MN), and thermophilic lyophilized yogurt cultures were obtained from Chr. Hansen (Hørsholm, Denmark). Sodium alginate and bile bovine were purchased from Sigma-Aldrich Co. (St. Louis, MO); de Man, Rogosa, and Sharpe (MRS) broth and agar were from Oxoid Inc. (Basingstoke, UK); peptone was from EMD Chemicals Inc. (Gibbstown, $\mathrm{NJ}$ ); and $\mathrm{CaCl}_{2} \cdot \mathrm{H}_{2} \mathrm{O}, \mathrm{HCl}, \mathrm{NaCl}$, $\mathrm{NaH}_{2} \mathrm{PO}_{4}$, and $\mathrm{Na}_{2} \mathrm{HPO}_{4}$ were of analytical reagent grade. Pasteurized and homogenized milk was obtained from Ataturk University's Dairy Processing Plant (Erzurum, Turkey), and skim milk powder (Pinar Dairy Products Inc., Izmir, Turkey) was purchased from a local store.

\section{Bacterial Growth Conditions}

Lyophilized cultures of ATCC 4356 were prepared by sequential transfer twice into MRS broth cultures were then incubated anaerobically at $37^{\circ} \mathrm{C}$ for $18 \mathrm{~h}$. Following overnight incubation, the media-containing cells were centrifuged at $3,900 \times g$ for $10 \mathrm{~min}$ at $4^{\circ} \mathrm{C}$, after which the supernatant was removed and the cells further washed twice $\left(3,900 \times g\right.$ for $10 \mathrm{~min}$ at $\left.4^{\circ} \mathrm{C}\right)$ in sterile $0.1 \%$ (wt/vol) peptone water. The washed cells were suspended to approximately $10^{10} \mathrm{cfu} / \mathrm{mL}$ in peptone water by comparing optical density to a previously prepared standard curve $\left(\mathrm{R}^{2} \geq 0.9\right.$; data not shown).

\section{Encapsulation}

Bacterial cells were encapsulated in alginate by the modified extrusion method of Muthukumarasamy et al. (2006). Briefly, $10 \mathrm{~g}$ of cell suspension $\left(\sim 10^{10} \mathrm{cfu} / \mathrm{mL}\right)$ was mixed with $50 \mathrm{~g}$ of a $4 \%$ sterile sodium alginate solution with continuous gentle stirring to immobilize the bacteria. The alginate-culture mixture was then added using a sterile glass syringe with regular-bevel 21-gauge needle, into $250 \mathrm{~mL}$ of $0.2 \mathrm{M}$ of $\mathrm{CaCl}_{2}$ with stirring at $300 \mathrm{rpm}$. The syringe needle was held 10 $\mathrm{cm}$ above the calcium solution and the alginate-culture mixture added dropwise to maintain a constant droplet size, as described by Krasaekoopt et al. (2003). The sodium alginate within the droplets was cross-linked to form calcium-alginate beads as they entered the calcium solution and were retained in the calcium solution for $30 \mathrm{~min}$ to gain rigidity. The solidified beads were then collected by filtration through Whatman \#4 filter paper and washed with sterile water (Ellenton, 1998).

\section{Capsule Attributes}

Fifty capsules were randomly collected and their diameter measured by visual observation against a millimeter-scale ruler. The shape of the capsules was 
observed visually, photographed using a Sony DSCW370 14 MP digital camera (Sony Electronics Inc., San Diego, CA), and the image enhanced using Adobe Photoshop Elements 7 (Adobe Inc., San Jose, CA) to improve capsule appearance.

\section{Yogurt Manufacture}

Pasteurized and homogenized bovine milk containing $2 \%$ fat was fortified with skim milk powder to $15 \%$ TS content and heated to $43^{\circ} \mathrm{C}$. Warmed milk was inoculated with thermophilic yogurt cultures according to the yogurt manufacturer's directions, and $9 \mathrm{~g}$ of inoculated milk was poured into each of $20(50-\mathrm{mL})$ sterile plastic tubes. All samples were incubated at $43^{\circ} \mathrm{C}$ until the $\mathrm{pH}$ reached $4.6(\sim 3.5 \mathrm{~h})$. Yogurt samples were kept at $4^{\circ} \mathrm{C}$ for $12 \mathrm{~h}$; free bacteria were added to 10 of the samples and alginate-encapsulated bacteria were added to the remaining 10 samples. All yogurt samples were mixed thoroughly and stored at $4^{\circ} \mathrm{C}$ for $28 \mathrm{~d}$. Then, ATCC 4356 were enumerated at $0,7,14,21$, and $28 \mathrm{~d}$ to observe the relative survival rates of the free versus encapsulated bacteria.

\section{Bacterial Enumeration}

Bacteria were enumerated from yogurt containing free ATCC 4356 after mixing $10 \mathrm{~g}$ of yogurt with 90 $\mathrm{mL}$ of $0.1 \%$ peptone water in a stomacher for $10 \mathrm{~min}$. For yogurt containing encapsulated ATCC 4356, 0.2 M phosphate buffer ( $\mathrm{pH} 7$ ) was used instead of peptone water to disrupt the alginate gel and release the encapsulated bacteria. Strain ATCC 4356 was selectively enumerated on MRS agar containing $0.2 \%$ bile (Lima et al., 2009). Bacterial enumerations were performed after $0,7,14,21$, and $28 \mathrm{~d}$ of refrigerated storage of yogurt samples.

\section{pH Analysis}

The $\mathrm{pH}$ of all yogurt samples was measured by using a digital $\mathrm{pH}$ meter ( $\mathrm{pH}$ meter 211, Hanna Inc., Ann Arbor, MI) by directly submerging the probe into the yogurt samples. The $\mathrm{pH}$ meter was calibrated using reference $\mathrm{pH} 4.0$ and $\mathrm{pH} 7.0$ buffer solutions.

\section{Artificial Gastric Digestive System}

To investigate the influence of $\mathrm{pH}$ on survival of probiotic bacteria, sterile-filtered AGJ based on Sun and Griffiths (2000) containing $0.2 \% \mathrm{NaCl}$ was prepared using $0.08 \mathrm{~N} \mathrm{HCl}$ at a final $\mathrm{pH}$ of 1.5 . Before adding $1 \mathrm{~g}$ of Ca-alginate capsules or free ATCC 4356, $9 \mathrm{~g}$ of AGJ was tempered to $37^{\circ} \mathrm{C}$, and the mixture was held at $37^{\circ} \mathrm{C}$ for up to $2 \mathrm{~h}$ with periodic shaking. The samples were taken at $0,30,60$, and 120 min during incubation in AGJ and spread-plated on MRS agar followed by anaerobic incubation at $37^{\circ} \mathrm{C}$ for $48 \mathrm{~h}$. The experiments were performed in duplicate and the results were presented in mean number of surviving bacteria \pm standard deviation.

\section{Artificial Bile Juice}

Artificial bile juice (ABJ; Klaenhammer and Kleeman, 1981; Song et al., 2003) was prepared by adding $1.2 \%$ bile into MRS broth prewarmed to the $37^{\circ} \mathrm{C}$. One gram of capsule was added to $9 \mathrm{~g}$ of ABJ and then incubated for $6 \mathrm{~h}$ at $37^{\circ} \mathrm{C}$ with periodic shaking. The samples were taken at 0 and 360 min of incubation in ABJs and spread-plated on MRS agar in which anaerobic incubation at $37^{\circ} \mathrm{C}$ for $48 \mathrm{~h}$ was performed. The experiments were performed in duplicate and the results were presented in mean number of surviving bacteria \pm standard deviation.

\section{Sensorial Evaluation}

Yogurt was manufactured as described above in 1-kg batches with free ATCC 4356 added to one batch, and encapsulated ATCC 4356 added to the second batch; the control batch contained only the yogurt starter cultures. The yogurts were mixed thoroughly and ten 100-g yogurt samples were dispensed from each batch into 10 plastic cups. Three types of yogurt samples were evaluated by 10 well-trained panelists using a hedonic-type scale from 1 to 9 , where 1 = least desirable and $9=$ most desirable. Panelists evaluated the 3 types of yogurts in terms of appearance and color, body and texture, flavor, odor, and overall liking. A score of 5 was considered as the limit of acceptability or unacceptability. The experiments were performed in duplicate and the results were presented as mean scores \pm standard deviation.

\section{Statistical Analysis}

For comparisons, the percentage survival in each treatment, instead of real numbers, was used to determine the change in the survival of $L b$. acidophilus ATCC 4356 over time (Adhikari et al., 2003). Percentage survival of bacteria during storage and as a consequence of AGJ or ABJ incubation were analyzed using ANOVA, and differences between means were evaluated by the Duncan multiple comparison test using SPSS 13.0.0.246 for Windows (SPSS Inc., Chicago, IL) as a 2-way factorial, with encapsulation as the treatment effect with 2 replicates. The sensorial evaluation 
Table 1. Effect of encapsulation on the viability of Lactobacillus acidophilus ATCC 4356 and pH in stirred-type yogurts over a period of $28 \mathrm{~d}$ at $4^{\circ} \mathrm{C}$ (means $\left.\pm \mathrm{SD}\right)$

\begin{tabular}{|c|c|c|c|c|c|c|c|}
\hline \multirow[b]{2}{*}{ Day } & \multirow[b]{2}{*}{ No. } & \multicolumn{3}{|c|}{ Encapsulated } & \multicolumn{3}{|c|}{ Free } \\
\hline & & Actual count ${ }^{1}$ & $\mathrm{pH}$ & Survival $(\%)^{2}$ & Actual count & $\mathrm{pH}$ & Survival (\%) \\
\hline 0 & 4 & $8.26 \pm 0.014$ & $4.54 \pm 0.014$ & $100^{\mathrm{a}, \mathrm{x}}$ & $9.47 \pm 0.021$ & $4.54 \pm 0.007$ & $100^{\mathrm{a}, \mathrm{x}}$ \\
\hline 7 & 4 & $7.83 \pm 0.127$ & $4.51 \pm 0.049$ & $94.79^{\mathrm{b}, \mathrm{x}}$ & $8.68 \pm 0.014$ & $4.59 \pm 0.098$ & $91.66^{\mathrm{b}, \mathrm{x}}$ \\
\hline 14 & 4 & $7.53 \pm 0.091$ & $4.37 \pm 0.028$ & $91.16^{\mathrm{c}, \mathrm{x}}$ & $8.48 \pm 0.148$ & $4.43 \pm 0.007$ & $89.55^{\mathrm{b}, \mathrm{x}}$ \\
\hline 21 & 4 & $7.42 \pm 0.176$ & $4.38 \pm 0.014$ & $89.83^{\mathrm{c}, \mathrm{x}}$ & $8.71 \pm 0.120$ & $4.30 \pm 0.070$ & $91.97^{\mathrm{b}, \mathrm{x}}$ \\
\hline 28 & 4 & $7.16 \pm 0.071$ & $4.38 \pm 0.007$ & $86.68^{\mathrm{c}, \mathrm{x}}$ & $8.56 \pm 0.042$ & $4.37 \pm 0.007$ & $90.39^{\mathrm{b}, \mathrm{x}}$ \\
\hline Significance & & $* *$ & $* *$ & $* *$ & $* *$ & $* *$ & $* *$ \\
\hline
\end{tabular}

\footnotetext{
${ }^{a-c}$ Means within a same column with the same letters are not significantly different at ${ }^{* *} P<0.01$ by Duncan multiple comparisons.

${ }^{\mathrm{x}}$ Means within same row with same letters are not significantly different $(P>0.05)$.

${ }^{1} \log _{10} \mathrm{cfu} / \mathrm{g}$ of yogurt.

${ }^{2}$ Calculated by dividing the final viable population $(\mathrm{cfu} / \mathrm{g})$ by initial viable population $(\mathrm{cfu} / \mathrm{g})$ of the test organism.
}

data and $\mathrm{pH}$ changes in yogurts were analyzed using ANOVA and differences between means were evaluated by the Duncan multiple comparison test using SPSS 13.0.0.246 for Windows. Significance was declared at $P \leq 0.05$.

\section{RESULTS AND DISCUSSION}

\section{pH Alterations of Yogurts During Refrigerated Storage}

The $\mathrm{pH}$ changes in the yogurts containing free and encapsulated probiotic bacteria during storage at $4^{\circ} \mathrm{C}$ for $4 \mathrm{wk}$ are shown in Table 1. Both yogurt samples had similar $\mathrm{pH}$ fluctuations through the $28 \mathrm{~d}$ of refrigerated storage. The $\mathrm{pH}$ of yogurts was 4.54 and 4.54 during the first day of storage and decreased to 4.37 and 4.38 at the end of the storage period for yogurts with free and encapsulated bacteria, respectively. These results were similar to those found by Krasaekoopt et al. (2006). They reported that the initial percentage acidity of yogurts containing free and encapsulated Lb. acidophilus was equal (at $\mathrm{d} 0$ ), and the percentage acidity of 2 types of yogurts was the same at the end of 4 wk of storage. Kailasapathy (2006) reported less post-acidification when encapsulated probiotic bacteria were added to yogurt.

\section{Survival of ATCC 4356 During 28 Days of Refrigerated Storage}

The reductions in the numbers of free and encapsulated ATCC 4356 in yogurts after $28 \mathrm{~d}$ of refrigerated storage are shown in Table 1. No differences were observed in the numbers of probiotic bacteria incorporated in yogurts before or after yogurt fermentation (Krasaekoopt et al., 2006). Therefore, we preferred to add the free and encapsulated ATCC 4356 cells into the yogurts after fermentation to ensure homogeneous mixing of the capsules in yogurt and to avoid sedimentation of capsules during fermentation.

Initial numbers of probiotic ATCC 4356 in yogurts were 9.47 and $8.26 \mathrm{log} \mathrm{cfu} / \mathrm{g}$ and decreased to 8.56 and $7.16 \log \mathrm{cfu} / \mathrm{g}$ at the end of the refrigerated storage for yogurts containing free and encapsulated bacteria, respectively. The reduction $(\sim 1 \log \mathrm{cfu} / \mathrm{g})$ in the numbers of free and encapsulated ATCC 4356 over 4 wk was similar and statistically significant $(P<0.01)$. This 1-log reduction was probably due to the bactericidal activity of lactic and acetic acids produced by the yogurt starters and $\beta$-galactosidase activity during storage of yogurts (post-acidification). Similar results were reported by Sultana et al. (2000), who observed reductions of 0.75 and $0.57 \mathrm{log} \mathrm{cfu} / \mathrm{g}$ in the numbers of free and encapsulated Lb. acidophilus 2401 during $4 \mathrm{wk}$ of refrigerated storage, respectively. In contrast, Krasaekoopt et al. (2006) and Kailasapathy (2006) reported that encapsulation increased the viability of $L b$. acidophilus during $4 \mathrm{wk}$ of refrigerated storage of stirred-type yogurts. In our experiment, however, the reductions in the numbers of free and encapsulated probiotic Lb. acidophilus ATCC 4356 did not exceed $1 \log$ over 28 d refrigerated storage of yogurts and, as mentioned above, we obtained relatively better survival of both free and encapsulated probiotic ATCC 4356 than did Krasaekoopt et al. (2006) and Kailasapathy (2006). The greater survival in the present study was probably due to the use of larger capsules, use of different strains, or occurrence of different post-acidifications in yogurts during refrigerated storage.

\section{Survival of ATCC 4356 in Artificial Gastric and Bile Juices}

When ATCC 4356 was incubated in $0.08 \mathrm{~N} \mathrm{HCl}$ at a $\mathrm{pH}$ of 1.5 (AGJ), the numbers of free ATCC 4356 
decreased from $10^{9}$ to $6 \times 10^{2} \mathrm{cfu} / \mathrm{g}$ after a 30-min exposure of the bacteria to the AGJ $(P<0.01)$. We observed only a $0.25-\log$ reduction (from $1.8 \times 10^{8}$ to $\left.8 \times 10^{7} \mathrm{cfu} / \mathrm{g} ; P>0.05\right)$ in the numbers of encapsulated ATCC 4356 after a 30-min exposure to AGJ (Table 2). Free ATCC 4356 did not survive (detectable level was $10^{2} \mathrm{cfu} / \mathrm{g}$ ) after a 60 -min incubation in AGJ. Nonetheless, encapsulated ATCC 4356 survived at a significantly higher rate (77\% after a 60 -min incubation in AGJ; $P<0.05)$. The viability rate of encapsulated ATCC 4356 after a 2-h incubation in AGJ was $61.54 \%$ $\left(\sim 10^{5}\right)$, which is close to the therapeutic minimum $\left(10^{6}\right)$ for probiotics.

The environment inside the capsules most likely protected the Ca-alginate encapsulated cells from high acidic stress factors via restriction of acid diffusion into the beads. Encapsulation clearly exerts a protective effect on Lb. acidophilus ATCC 4356 cells in AGJ. According to Sun and Griffiths (2000), this protection is due to the formation of a $\mathrm{pH}$ gradient in beads, which depends on bead size and the exposure time of the beads in AGJ. Therefore, when placed into AGJ, free cells were exposed to the extremely low $\mathrm{pH}$ immediately; whereas beads were subjected to a different $\mathrm{pH}$, which provides protection to the bacteria against the hyper-acidic conditions in the capsules. In this study, about $10^{5} \mathrm{cfu} / \mathrm{g}$ of ATCC 4356 cells would be alive when $2 \times 10^{8} \mathrm{cfu} / \mathrm{g}$ of cells in beads were incubated in AGJ (pH 1.5) for $120 \mathrm{~min}$.

It generally takes about $90 \mathrm{~min}$ to empty half the human stomach, which has a pH of 1 to 3 (Giannella et al., 1972). Therefore, it is beneficial to bacteria if they have enough protection to survive the 90-min transit through the harsh acidic environment of the stomach.
Encapsulation limits the exposure of bacteria to gastric juice by slowing the rate of diffusion of gastric juice into the cells. The rate of diffusion is determined by capsule size (Sun and Griffiths, 2000; Muthukumarasamy et al., 2006) and the concentration of alginate used to encapsulate the bacteria (Mandal et al., 2006). Larger capsules (Figure 1) obtained by the extrusion method (1.5 to $2.5 \mathrm{~mm}$ ) provide greater protection because the distance between the gastric acid and the cell is increased, diffusion time is therefore increased, and consequently, bacteria survival rate is increased.

In addition to above-mentioned deceleration of diffusion mechanisms, the other reason for the higher survival rates in the encapsulated cells in our study may be that in larger $(\sim 2-\mathrm{mm})$ capsules the bacteria in the outer regions (which are more exposed to the acid) die off, while the bacteria in the inner regions are protected. This would also explain having only a $\sim 3-\log$ reduction in encapsulated ATCC 4356 compared with no survival ( $>7-\log$ loss) of free bacteria.

The results of present study overlap with those reported by Krasaekoopt et al. (2004), who encapsulated $L b$. acidophilus in large alginate capsules at an average diameter of $1.62 \mathrm{~mm}$. They also observed greater survival of encapsulated bacteria with only a 3.2-log reduction $\left(1.6 \times 10^{9}\right.$ to $\left.8.5 \times 10^{5}\right)$ compared with a 5.9-log reduction in free bacteria $\left(2 \times 10^{9}\right.$ to $\left.2.3 \times 10^{3}\right)$. Muthukumarasamy et al. (2006) also observed a good protective effect of large alginate capsules with an average diameter of $2.37 \mathrm{~mm}$. They reported that larger ( 2 to $4 \mathrm{~mm}$ ) extruded capsules protected the $L b$. casei cells better than the smaller $(20 \mu \mathrm{m}$ to $1 \mathrm{~mm})$ emulsified capsules simply by increasing the distance between encapsulated cells and the surrounding acid. Lee and

Table 2. Mean counts (means $\pm \mathrm{SD}$ ) and percentage (\%) survival $(\mathrm{n}=2)$ of encapsulated and free Lactobacillus acidophilus ATCC 4356 during incubation in artificial gastric juice (AGJ) or artificial bile juice (ABJ)

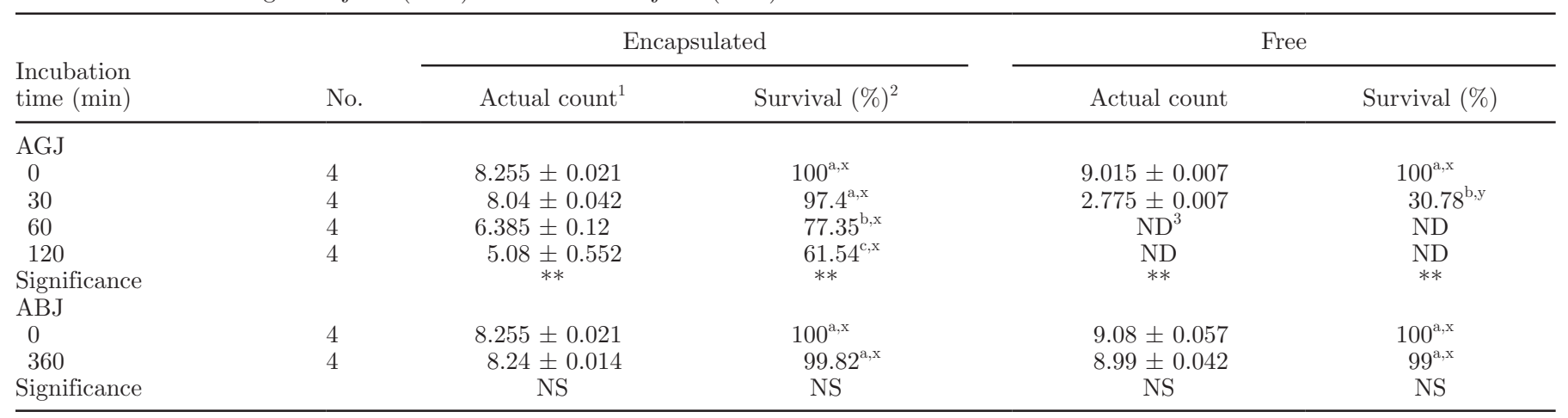

\footnotetext{
${ }^{\mathrm{a}-\mathrm{c}}$ Means within a same column with same letters are not significantly different at ${ }^{* *}(P<0.05)$.

${ }^{\mathrm{x}, \mathrm{y}}$ Means within same row with same letters are not significantly different $(P<0.05)$.

${ }^{1} \log _{10} \mathrm{cfu} / \mathrm{g}$ of capsule.

${ }^{2}$ Calculated by dividing the final viable population $(\mathrm{cfu} / \mathrm{g})$ by initial viable population $(\mathrm{cfu} / \mathrm{g})$ of the test organism inoculated in AGJ and ABJ.

${ }^{3}$ Not detected (detectable level was $10^{2} \mathrm{cfu} / \mathrm{g}$ ).
} 


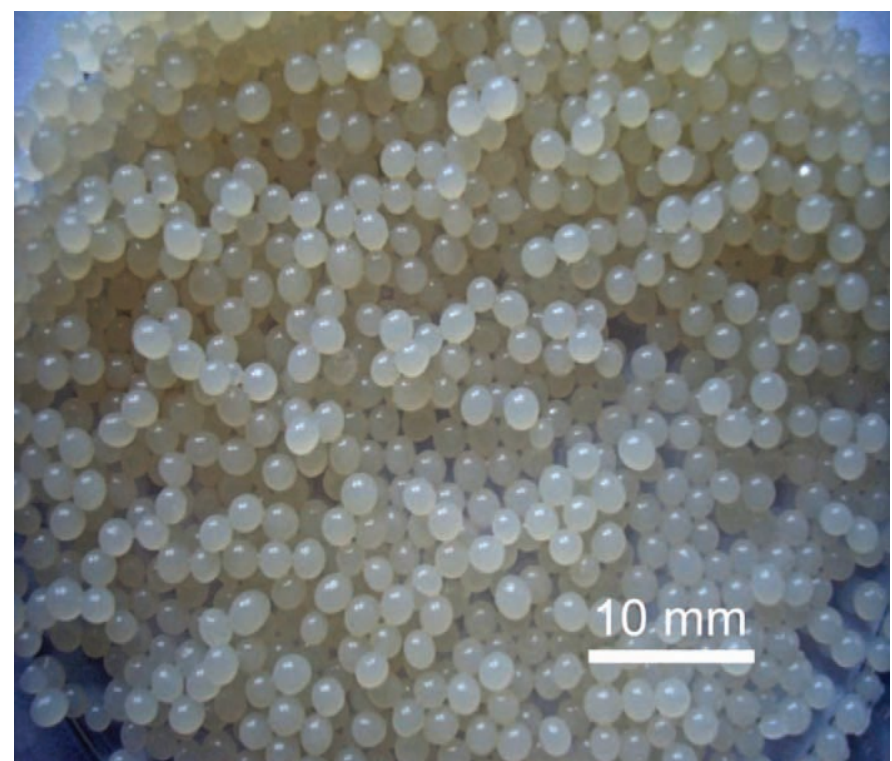

Figure 1. Calcium alginate capsules containing probiotic Lactobacillus acidophilus ATCC 4356 encapsulated by the extrusion method. Color version available in the online PDF.

Heo (2000) reported that when bifidobacteria encapsulated in calcium alginate capsules were subjected to AGJ (pH 1.55) and a bile salt solution, the death rate of cells in the beads decreased proportionally with an increase in alginate gel concentration and in bead size.

When the encapsulated and free ATCC 4356 were incubated in ABJ for 360 min, no reductions occurred in the numbers of both encapsulated and free ATCC 4356 cells $(P>0.05$; Table 2$)$. It is known that probiotic ATCC 4356 has bile tolerance. Similar results were reported by Kim et al. (2008), who observed no loss of free and encapsulated Lb. acidophilus ATCC 43121 after a 6-h incubation in artificial intestinal juice (AIJ). Nonetheless, they reported a significant protective effect of encapsulation on the viability of $L b$. acidophilus ATCC 43121 after 24 h. Free Lb. acidophilus ATCC 43121 had a 1-log loss but encapsulated bacteria did not have a significant loss after a 24 -h incubation in AIJ at $37^{\circ} \mathrm{C}$. Brinques and Ayub (2011) also reported that viability of free and encapsulated Lb. plantarum BL011 was not affected by AIJ, and noted that BL011 has a natural resistance to bile, similar to that of ATCC 4356.

As mentioned above, most of the probiotic bacteria survive or even recover in the intestinal tract because once the encapsulated bacteria leave the stomach and enter the neutral $\mathrm{pH}$ environment of the intestines, the capsules are neutralized by intestinal juice, the capsules are softened, and might be broken by the peristalsis of the small intestine, resulting in release of the probiotic bacteria (Sun and Griffiths, 2000). As Antoine (2011) observed, this neutralization and release allow the probiotics to metabolize normally and resume growth. Although the luminal detergent bile salts still interfere with the cell membrane of dividing bacteria, the glucose-rich digesta in the gut lumen will provide a more readily available source of energy than lactose. Therefore, it will not be a challenge for probiotic bacteria to shift from an acid dairy matrix to a warm nutrient-rich gut lumen.

When probiotic bacteria are consumed with foods, the food matrix itself provides some protection. However, Sharp et al. (2008) have shown that when yogurts containing probiotic bacteria were added into an AGJ in which the $\mathrm{pH}$ was constant (no buffering), the survivability of bacteria was $<10^{1} \mathrm{cfu} / \mathrm{g}$ after a $30-\mathrm{min}$ exposure to this acidic environment. Therefore, yogurt itself may provide little protection to the viability of ingested probiotic bacteria. As a result, consumption of yogurts containing larger capsules might increase the survival rate of the probiotic bacteria in the gastrointestinal tract compared with consumption as a pure liquid culture. Thus, consumers would more benefit from the therapeutic effects of these health-promoting microbes in encapsulated forms.

\section{Sensorial Evaluation}

Statistical analysis showed that the sensorial scores of 3 types of yogurts differed only for body and texture $(P$ $<0.05$ ); none of the other sensorial characteristics were statistically significant $(P>0.05)$. Yogurts that contained encapsulated ATCC 4356 had the lowest overall liking score (5.65 out of 9), and the control yogurts (no additional probiotic bacteria) had the highest overall liking score (6.9 out of 9 ); a score of 5 was considered the limit of acceptability (Table 3 ).

The body/texture of yogurts containing encapsulated ATCC 4356 was below the acceptable level (4.7 out of 9) and body/texture was considered a defect in the encapsulated type of yogurts by the panelists. Control yogurts and those containing free ATCC 4356 had acceptable scores of 6.6 and 5.6, respectively, in terms of body/texture. Panelists complained about the coarser texture of the yogurts that contained encapsulated ATCC 4356. Similar results were reported by Kailasapathy (2006), who observed a significant change in the textural properties, particularly smoothness, of yogurts containing microencapsulated probiotic bacteria. In our study, the capsules were approximately $2 \mathrm{~mm}$ in diameter and were thus visible to the panelists, which is an undesirable quality parameter for yogurt. Utilization of exopolysaccharide-producing probiotic cultures 
Table 3. Sensory evaluation scores (mean $\pm \mathrm{SD}$ ) of yogurts ${ }^{1}$

\begin{tabular}{|c|c|c|c|c|c|c|}
\hline Treatment $^{2}$ & No. & $\begin{array}{l}\text { Appearance } \\
\text { and color }\end{array}$ & $\begin{array}{l}\text { Body and } \\
\text { texture }\end{array}$ & Flavor & Odor & Overall liking \\
\hline Yogurt + EnLa & 10 & $6.0 \pm 1.33^{\mathrm{a}}$ & $4.7 \pm 1.57^{\mathrm{b}}$ & $5.8 \pm 1.47^{\mathrm{a}}$ & $6.8 \pm 0.92^{\mathrm{a}}$ & $5.65 \pm 1.56^{\mathrm{a}}$ \\
\hline Yogurt + FLa & 10 & $6.5 \pm 1.43^{\mathrm{a}}$ & $5.6 \pm 1.51^{\mathrm{ab}}$ & $6.1 \pm 2.08^{\mathrm{a}}$ & $6.5 \pm 0.85^{\mathrm{a}}$ & $6.2 \pm 1.47^{\mathrm{a}}$ \\
\hline Significance & & NS & $*$ & NS & NS & NS \\
\hline
\end{tabular}

${ }^{a, b}$ Mean values within a column with the same letters are not significantly different from each other at $P<0.05\left(^{*}\right)$ by Duncan multiple comparison test.

${ }^{1}$ Average of 2 replications, with each replicate analyzed in duplicate. Sensory attributes were scored on a 1 to 9 scale, where $9=$ most desirable, $5=$ acceptable, 1 = least desirable.

${ }^{2} \mathrm{EnLa}=$ encapsulated Lactobacillus acidophilus ATCC 4356; FLa = free (nonencapsulated) Lb. acidophilus ATCC 4356; Control = yogurts that contained no additional probiotic bacteria (starter cultures only).

or addition of polysaccharides to tighten the yogurt gel might improve the body and textural attributes of yogurts containing larger capsules.

\section{CONCLUSIONS}

During 4-wk refrigerated storage of yogurts containing $L$ b. acidophilus ATCC 4356, we observed a 1-log reduction in free and encapsulated ATCC 4356. When free ATCC 4356 was incubated for $2 \mathrm{~h}$ in $\mathrm{HCl}-\mathrm{NaCl}$ solution ( $\mathrm{pH}$ 1.5) to simulate gastric digestion, we observed no survival ( $>7-\log$ reduction) of the probiotic strain. Encapsulating the probiotic strain in 2-mm alginate capsules increased its survivability by $>4 \operatorname{logs}$, with only a 3-log reduction occurring. Incubation of the probiotic in ABJ resulted in no decrease in ATCC 4356 counts. Overall liking scores did not differ for the control yogurt (no additional probiotic) and yogurts containing free ATCC 4356 or encapsulated ATCC 4356, but the yogurt with encapsulated bacteria had the lowest score for texture and had a noticeably coarser texture. Further research is needed to determine an optimal capsule size that will provide adequate protection during gastric digestion without adversely affecting textural attributes (smoothness) of yogurt.

\section{ACKNOWLEDGMENTS}

We thank Donald J. McMahon (Western Dairy Center, Logan, UT) for his generous support in the process of this research and Nolan Weil (Utah State University, Logan) for valuable editorial assistance during the drafting of this manuscript. Thanks to Meltem Cetin (Ataturk University, Erzurum, Turkey) for support during the encapsulation process, Xin Dai (Utah State University, Logan) for performing statistical analysis, and Hilal Yildiz (Gumushane University, Gumushane, Turkey) for support during media preparation. This research was financially supported by Ataturk University BAP Commission (BAP 2009/10).

\section{REFERENCES}

Adhikari, K., A. Mustapha, and I. U. Grün. 2003. Survival and metabolic activity of microencapsulated Bifidobacterium longum in stirred yogurt. J. Food Sci. 68:275-280.

Antoine, J. M. 2011. Current challenges for probiotics in food. Pages 220-221 in Lactic Acid Bacteria: Microbiological and Functional Aspects. 4th ed. S. Lathinen, A. C. Ouwehand, S. Salminen, and A. V. Wright, ed. CRC Press, London, UK.

Brinques, G. B., and M. A. Z. Ayub. 2011. Effect of microencapsulation on survival of Lactobacillus plantarum in simulated gastrointestinal conditions, refrigeration, and yogurt. J. Food Eng. 103:123-128.

Champagne, C. P., N. J. Gardner, and D. Roy. 2005. Challenges in the addition of probiotic cultures to foods. Crit. Rev. Food Sci. Nutr. 45:61-84.

Ding, W. K., and N. P. Shah. 2009. Effect of various encapsulating materials on the stability of probiotic bacteria. J. Food Sci. 74:M100-M107.

Ellenton, J. C. 1998. Cellular morphology of bifidobacteria and their survival when encapsulated in calcium alginate beads. MS Thesis. University of Guelph, ON, Canada.

Giannella, R. A., S. A. Broitman, and N. Zamcheck. 1972. Gastric acic barrier to ingested microorganisms in man: Studies in vivo and in vitro. Gut 13:251-256.

Hansen, L. T., P. M. Allan-Wojtas, Y. L. Jin, and A. T. Paulson. 2002 Survival of Ca-alginate microencapsulated Bifidobacterium spp. in milk and simulated gastrointestinal conditions. Food Microbiol. 19:35-45.

Homayouni, A., A. Azizi, M. R. Ehsani, M. S. Yarmand, and S. H. Razavi. 2008. Effect of microencapsulation and resistant starch on the probiotic survival and sensory properties of synbiotic ice cream. Food Chem. 111:50-55.

Kailasapathy, K. 2006. Survival of free and encapsulated probiotic bacteria and their effect on the sensory properties of yoghurt. Lebenson. Wiss. Technol. 39:1221-1227.

Kim, S.-J., S. Y. Cho, S. H. Kim, O.-J. Song, S. Shin, D. S. Cha, and H. J. Park. 2008. Effect of microencapsulation on viability and other characteristics in Lactobacillus acidophilus ATCC 43121. Lebenson. Wiss. Technol. 41:493-500.

Klaenhammer, T. R., and E. G. Kleeman. 1981. Growth characteristics, bile sensitivity and freeze damage in colonial variants of $L a c$ tobacillus acidophilus. Appl. Environ. Microbiol. 41:1461-1467.

Krasaekoopt, W., B. Bhandari, and H. Deeth. 2003. Evaluation of encapsulation techniques of probiotics for yoghurt. Int. Dairy J. 13:3-13.

Krasaekoopt, W., B. Bhandari, and H. Deeth. 2004. The influence of coating materials on some properties of alginate beads and survivability of microencapsulated probiotic bacteria. Int. Dairy J. 14:737-743.

Krasaekoopt, W., B. Bhandari, and H. C. Deeth. 2006. Survival of probiotics encapsulated in chitosan-coated alginate beads in yo- 
ghurt from UHT- and conventionally treated milk during storage. Lebenson. Wiss. Technol. 39:177-183.

Lee, K. Y., and T. R. Heo. 2000. Survival of Bifidobacterium longum immobilized in calcium alginate beads in simulated gastric juices and bile salt solution. Appl. Environ. Microbiol. 66:869-873.

Lima, K. G. C., M. F. Kruger, J. Behrens, M. T. Destro, M. Landgraf, and B. D. G. M. Franco. 2009. Evaluation of culture media for enumeration of Lactobacillus acidophilus, Lactobacillus casei and Bifidobacterium animalis in the presence of Lactobacillus delbruckii subsp bulgaricus and Streptococcus thermophilus. Food Sci. Technol. 42:491-495.

Lourens-Hattingh, A., and B. C. Viljoen. 2001. Yogurt as probiotic carrier food. Int. Dairy J. 11:1-17.

Mandal, S., A. K. Puniya, and K. Singh. 2006. Effect of alginate concentrations on survival of microencapsulated Lactobacillus casei NCDC-298. Int. Dairy J. 16:1190-1195.

Mattila-Sandholm, T., P. Myllärinen, R. Crittenden, G. Mogensen, R. Fondén, and M. Saarela. 2002. Technological challenges for future probiotic foods. Int. Dairy J. 12:173-182.

Muthukumarasamy, P. P. Allan-Wojtas, and R. A. Holley. 2006. Stability of Lactobacillus reuteri in different types of microcapsules. J. Food Sci. 71:M20-M24.

Ouwehand, A. C., and S. J. Salminen. 1998. The health effects of cultured milk products with viable and non-viable bacteria. Int. Dairy J. 8:749-758.

Ozer, B., H. A. Kirmaci, E. Senel, M. Atamer, and A. Hayaloglu. 2009. Improving the viability of Bifidobacterium bifidum BB-12 and Lactobacillus acidophilus LA-5 in white-brined cheese by microencapsulation. Int. Dairy J. 19:22-29.
Ozer, B., Y. S. Uzun, and H. A. Kirmaci. 2008. Effect of microencapsulation on viability of Lactobacillus acidophilus LA-5 and Bifidobacterium bifidum BB-12 during Kasar cheese ripening. Int. J. Dairy Technol. 61:237-244.

Sabikhi, L., R. Babu, D. K. Thompkinson, and S. Kapila. 2010. Resistance of microencapsulated Lactobacillus acidophilus LA1 to processing treatments and simulated gut conditions. Food Bioproc. Technol. 3:586-593.

Sharp, M. D., D. J. McMahon, and J. R. Broadbent. 2008. Comparative evaluation of yogurt and low-fat Cheddar cheese as delivery media for probiotic Lactobacillus casei. J. Food Sci. 73:M375M377.

Singh, K., B. Kallali, A. Kumar, and V. Thaker. 2011. Probiotics: A review. Asian Pacific J. Tropic. Biomed. XX:S287-S290.

Song, S. H., Y. H. Cho, and J. Park. 2003. Microencapsulation of Lactobacillus casei YIT 9018 using a microporous glass membrane emulsification system. J. Food Sci. 68:195-200.

Stanton, C., R. P. Ross, G. F. Fitzgerald, and D. Van Sinderen. 2005. Fermented functional foods based on probiotics and their biogenic metabolites. Curr. Opin. Biotechnol. 16:198-203.

Sultana, K., G. Godward, N. Reynolds, R. Arumugaswamy, P. Peiris, and K. Kailasapathy. 2000. Encapsulation of probiotic bacteria with alginate-starch and evaluation of survival in simulated gastrointestinal conditions and in yoghurt. Int. J. Food Microbiol. 62:47-55.

Sun, W., and M. W. Griffiths. 2000. Survival of bifidobacteria in yogurt and simulated gastric juice following immobilization in gellan-xanthan beads. Int. J. Food Microbiol. 61:17-25. 